\title{
Protein hidrolisat daging bekicot (Achatina fulica) sebagai pengurang penggunaan tepung ikan terhadap performa ayam kampung super
}

\section{Hydrolyzed protein of snail meat (Achatina fulica) as a reduction of fish meal on performance of "super" native chicken}

\author{
Ujang Suryadi ${ }^{1}$, Shokhirul Imam ${ }^{1}$, Aufa Fariza Ahmad ${ }^{1}$ \\ ${ }^{1}$ Program Studi Manajemen Bisnis Unggas, Jurusan Peternakan, Politeknik Negeri Jember. Jl. Mastrip P0.BOX 164 Jember. \\ Kode Pos 68121 \\ *Email Koresponden: ujang_suryadi@polije.ac.id
}

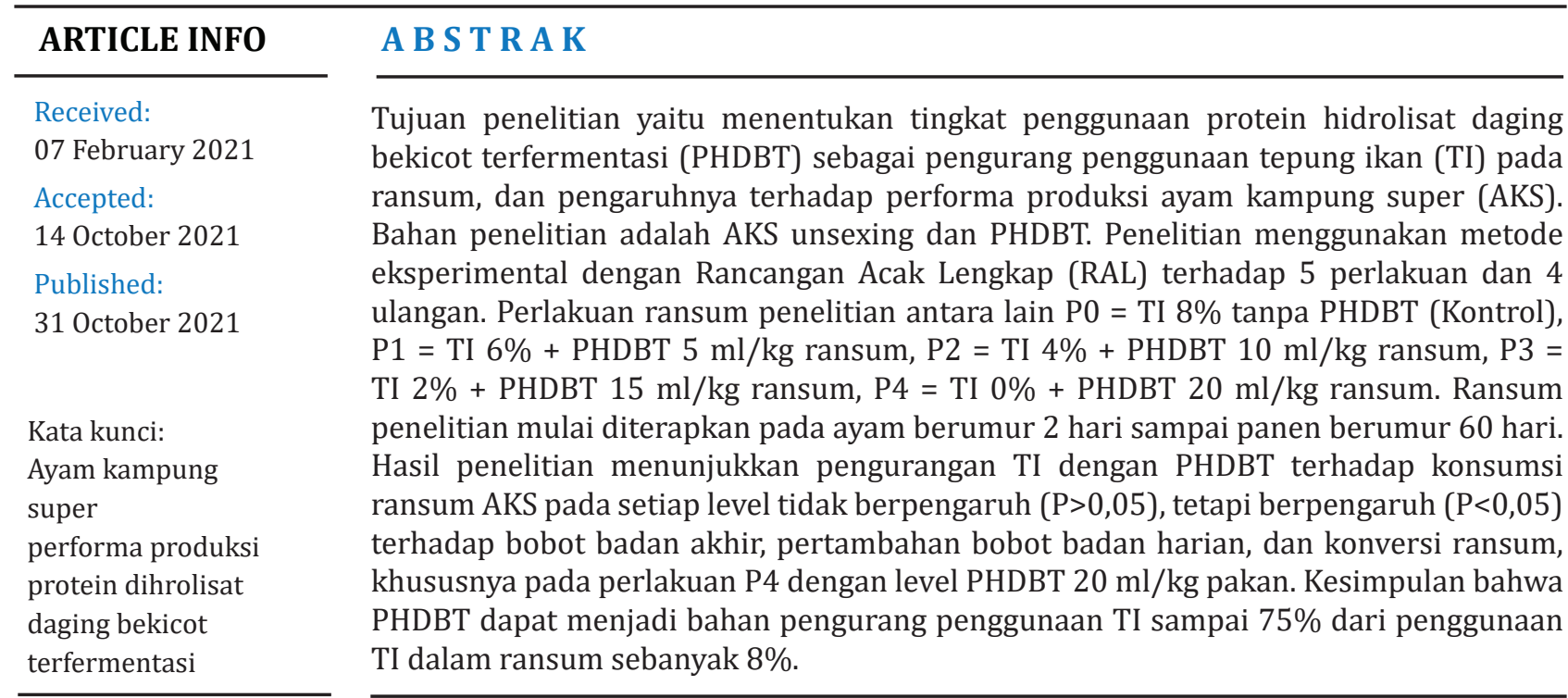

A B S T R A C T

The aim of the study was to determine the level of use of fermented snail meat protein hydrolyzate (FSMPH) as a reduction of fish meal (FM) in the ration, and its effect on the production performance of "super" native chicken (SNC). Research materials were SNC unsexing and FSMPH. The study used an experimental method with a completely randomized design with 5 treatments and 4 replications. The research ration treatments included PO = FM 8\% without FSMPH (Control), $P 1=F M 6 \%+F S M P H 5 \mathrm{ml} / \mathrm{kg}$ ration, $P 2=$ $F M 4 \%+F S M P H 10 \mathrm{ml} / \mathrm{kg}$ ration, $P 3=F M 2 \%+F S M P H 15 \mathrm{ml} / \mathrm{kg}$ ration, $P 4=F M 0 \%+F S M P H$

Key words:

"super" native

chicken

production

performance

fermented snail meat protein hydrolyzate
$20 \mathrm{ml} / \mathrm{kg}$ ration. Research rations began to be applied to chickens aged 2 days old until the harvest was 60 days old. The results showed that the a reduction of FM with FSMPH on SNC ration consumption at each level had no significant effect $(P>0.05)$ but presented a significant difference $(P<0.05)$ on lower final body weight, lower ADG and higher FCR, especially for treatment P4 with a FSMPH level of $20 \mathrm{ml} / \mathrm{kg}$ of feed. The conclusion was that FSMPH usage up to $75 \%$ can be used to reduce the FM percentage in the ration as much as $8 \%$

\section{PENDAHULUAN}

Ayam kampung super hasil persilangan antara ayam petelur dan ayam kampung (Pakaya et al., 2019), persilangan antara ayam kampung jantan dengan ayam ras betina memiliki pertumbuhan yang relatif cepat, umur 70 hari mencapai bobot badan $1-1,3 \mathrm{~kg}$, sedangkan ayam buras hanya $0,6 \mathrm{~kg}$ 
(Sriyanto, 2013), sehingga dapat digunakan sebagai penghasil daging yang memiliki karakteristik tekstur dan rasa hampir sama dengan ayam buras, hanya pertumbuhannya yang cepat sehingga umur panen cepat pula (Ma'rifah et al., 2013).

Pakan memegang peran terpenting untuk menunjang kesehatan dan pertumbuhan karena pakan dapat mensuplai energi sehingga proses metabolisme dapat berjalan serta tumbuh dan berkembang dengan baik (Suprijatna et al., 2008). Pengadaan pakan memerlukan biaya terbesar yaitu $60-80 \%$ dari seluruh biaya produksi pada ternak unggas. Pengadaan pakan ayam kampung super yang murah sudah banyak dilakukan oleh peternak dengan menformulasikan bahan pakan sendiri.

Penyusunan ransum ayam tidak terlepas dari penggunaan bahan pakan pokok unggas yang sangat penting adalah tepung ikan (Beski et al., 2015). Tepung ikan merupakan bahan pakan sumber protein penting dalam pakan unggas, namun memiliki harga yang relatif mahal. Oleh karena itu, penggunaann tepung ikan dalam pakan ayam kampung sekitar $2-15 \%$ dari total campuran bahan. Pembatasan penggunaan tepung ikan yang terlalu banyak dikhawatirkan dapat membuat ayam kehilangan selera makannya dan daging yang dihasilkan berbau amis (Nawawi \& Nurrohmah, 2013).

Mahalnya harga tepung ikan memerlukan alternatif bahan pakan lain yang murah dan dapat mengurangi penggunaan tepung ikan, mudah didapat dan bernutrisi tinggi, tidak kompetitif dengan kebutuhan lainnya, disukai ternak atau palatabilitas tinggi, tidak mengganggu kesehatan, dan tidak mengandung racun atau antinutrisi. Wakhid (2010) menyampaikan bahwa daging bekicot dapat dimanfaatkan sebagai bahan pakan unggas untuk mengganti tepung ikan karena mempunyai kandungan protein yang sebanding yaitu sekitar $60 \%$, mengandung asam amino dan mineral yang memenuhi persyaratan sebagai pakan bergizi, murah dan mudah diperoleh.

Penggunaan daging bekicot sebagai alaternatif pengganti tepung ikan pada ransum unggas sudah banyak diteliti dalam berbagai bentuk olahan seperti dibuat silase melalui proses fermentasi, dibuat menjadi tepung, atau diberikan segar tanpa pengolahan. Proses pengolahan daging bekicot melalui proses fermentasi dapat dimungkinkan untuk menghasilkan berbagai olahan lain disamping bentuk silase sesuai dengan prinsip fermentasi yaitu melibatkan menggunakan bakteri.

Fermentasi sering digunakan dalam pengawetan makanan karena rendah biaya dan menghasilkan produk yang memiliki nilai gizi lebih baik dibandingkan dengan bahan asalnya (Phakde et al., 2014). Irianto (2013) menyatakan bahwa fermentasi merupakan proses penguraian bahan organik yang kompleks menjadi senyawa yang lebih sederhana oleh aktivitas mikroba. Senyawa sederhana yang dihasilkan dari proses fermentasi dapat memberikan flavor dan aroma serta dapat meningkatkan daya cerna, memperbaiki nilai gizi dan daya simpan produk.

Berdasarkan hal tersebut, daging bekicot dapat buat menjadi sumber asam amino melalui proses hidrolisis dengan menggunakan jasa bakteri penghasil ezim proteolitik. Hidrolisis protein bekicot menjadi asam amino oleh kegiatan enzim protease melalu proses fermentasi diharapkan dapat meningkat nilai manfaat daging bekicot. Menurut Biyatmoko (2014), teknologi bio proses melalui teknik fermentasi mampu secara nyata memperbaiki kualitas nutrisi khususnya protein disebabkan oleh meningkatnya ketersediaan protein sel tunggal (PST) atau Single Cell Protein (SCP) asal kapang yang terbentuk selama proses fermentasi berlangsung. Fermentasi merupakan proses penguraian bahan organik yang kompleks menjadi senyawa yang lebih sederhana oleh aktivitas mikroba (Irianto, 2013). Senyawa sederhana yang dihasilkan dari proses fermentasi dapat memberikan flavor dan aroma serta dapat meningkatkan daya cerna, memperbaiki nilai gizi dan daya simpan produk. Tujuan penelitian yaitu menentukan kemampuan dan tingkat penggunaan protein hidrolisat daging keong sebagai pengurang penggunaan tepung ikan pada ransum, serta untuk mengetahui pengaruhnya terhadap performa produksi Ayam Kampung Super.

\section{MATERI DAN METODE}

\section{Materi Penelitian}

Penelitian ini menggunakan Day old Chicken Ayam Kampung Super unsexing dengan berat rata-rata 34,26 $\pm 0,78$ gram. Bahan pakan 
berupa konsentrat, dedak, jagung, tepung ikan, hidrolisat protein dari daging bekicot terfermentasi, kandang ayam, terpal, plastik tirai, air, koran, sekam, gamping, kapur bubuk.

\section{Prosedur Penelitian}

\section{Pembuatan hidrolisat protein daging bekicot terfermentasi}

Hidrolisat protein dibuat dari daging dan isi perut bekicot yang telah difermentasi dengan whey hasil dari fermentasi air susu sapi dengan peraman air beras. Whey hasil dari fermentasi air susu sapi merupakan lapisan bawah berupa cairan kuning yang kaya akan bakteri proteolitik. Fermentasi daging bekicot dilakukan dengan mencampurkan semua bahan ke dalam satu wadah yaitu whey hasil dari fermentasi air susu sapi, gula merah yang telah dicairkan, daging bekicot dan isi perut yang telah digiling halus dengan perbandingan (liter : liter : kg) yaitu 1 liter whey hasil dari fermentasi air susu sapi : 1 liter gula merah yang telah dicairkan : $1 \mathrm{~kg}$ daging bekicot dan isi perut yang telah digiling halus, kemudian difermentasi selama 3-4 minggu.

\section{Pemeliharaan ayam penelitian}

Ayam dipelihara dengan menggunakan kandang litter yang terbagi ke dalam 20 petak. Setiap petak berukuran $1 \mathrm{~m}^{2}$ yang dilengkapi liter sekam setinggi kurang lebih 5-7 cm, 1 buah tempat minum. Jumlah ayam dalam setiap petak adalah 10 ekor.

Tabel 1. Formulasi Ransum Perlakuan
Ayam diberi ransum yang sesuai dengan perlakuan dengan frekuensi 3 kali sehari. Ransum yang diberikan berbentuk crumble. Air minum diberikan secara adlibitum (tanpa batas). Hidrolisat protein daging bekicot sebagai pengurang penggunaan tepung ikan diberikan pada ayam umur 2 hari. Umur 4 ayam dilakukan vaksinasi menggunakan ND-IB aktif dengan aplikasi tetes mata dan umur 10 hari vaksin Gumboro dengan aplikasi cekok. Selama penelitian ayam dilakukan penimbangan bobot badan satu minggu satu kali dan pergantian sekam jika basah. Ransum yang diberikan pada ayam disesuaikan dengan perlakuan dengan kandungan nutrisi disajikan pada Tabel 1.

Pada formulasi ransum ditambahkan minyak kelapa dan premix masing masing $1 \%$. Hidrolisat protein daging bekicot terfermentasi ditambahkan sesuai perlakuan $\mathrm{P} 0=0 ; \mathrm{P} 1=5$; P2=10; P3=15; P4=20 ml/kg pakan dengan cara mencampurkan setiap waktu pemberian pakan secara merata dengan disemprotkan pada pakan yang telah disediakan dan adukaduk hingga merata, kemudian diberikan pada ayam kampung super sesuai dengan kebutuhan. Hidrolisat protein daging bekicot terfermentasi diberikan selama 2 bulan dimulai dari hari kedua hingga panen umur 60 hari.

\section{Metode Penelitian}

Penelitian ini mengguanakan metode eksperimental dengan Rancangan Acak Lengkap (RAL) yang terdiri dari 5 perlakuan dan 4 ulangan dengan perlakuan penelitian meliputi :

\begin{tabular}{|c|c|c|c|c|c|c|}
\hline \multirow{2}{*}{ No } & \multirow{2}{*}{ Bahan Pakan } & \multicolumn{5}{|c|}{ Ransum Perlakuan } \\
\hline & & P0 & P1 & P2 & P3 & $\mathrm{P} 4$ \\
\hline 1 & KBR (\%) & 26 & 27 & 27 & 28 & 28 \\
\hline 2 & Jagung Kuning (\%) & 56 & 57 & 58 & 59 & 61 \\
\hline 3 & Bekatul (\%) & 10 & 10 & 11 & 11 & 11 \\
\hline 4 & Tepung Ikan (\%) & 8 & 6 & 4 & 2 & 0 \\
\hline & TOTAL (\%) & 100 & 100 & 100 & 100 & 100 \\
\hline No & Komposisi Nutrisi (\%) & & & & & \\
\hline 1 & Protein Kasar (PK) & 20,49 & 19,72 & 18,92 & 18,09 & 17,22 \\
\hline 2 & Serat Kasar (SK) & 3,06 & 3,10 & 3,08 & 3,06 & 3,04 \\
\hline 3 & Lemak Kasar (LK) & 4,64 & 4,56 & 4,37 & 4,19 & 4,00 \\
\hline 4 & Energi Metabolis (EM) (kkal/kg) & 2385,20 & 2379,80 & 2325,71 & 2271,63 & 2217,55 \\
\hline 5 & Kalsium (Ca) & 1,24 & 1,15 & 1,04 & 0,92 & 0,81 \\
\hline 6 & Phospor (P) & 0,69 & 0,64 & 0,59 & 0,53 & 0,47 \\
\hline
\end{tabular}

Sumber: Perhitungan hasil kalkulasi 
$\mathrm{P0}=$ Tepung ikan 8\% tanpa daging bekicot terfermentasi (kontrol),

P1 = Tepung ikan 6\% + hidrolisat protein daging keong fermentasi $5 \mathrm{ml} / \mathrm{kg}$ ransum,

P2 = Tepung ikan 4\% + hidrolisat protein daging keong fermentasi $10 \mathrm{ml} / \mathrm{kg}$ ransum,

P3 = Tepung ikan $2 \%+$ hidrolisat protein daging keong fermentasi $15 \mathrm{ml} / \mathrm{kg}$ ransum,

P4 = Tepung ikan $0 \%+$ hidrolisat protein daging keong fermentasi $20 \mathrm{ml} / \mathrm{kg}$ ransum.

\section{Parameter Pengamatan}

\section{Konsumsi ransum}

Konsumsi ransum ayam kampung super dihitung berdasarkan jumlah pakan yang diberikan setiap hari (gram) dibagi dengan jumlah ayam (ekor), satuan dalam gram/ekor/ hari.

\section{Bobot badan akhir pemeliharaan}

Bobot badan akhir dihitung dengan menimbang bobot badan ayam pada umur 8 minggu, satuan yang digunakan kilogram.

\section{Pertambahan bobot badan (PBB)}

Pertambahan bobot badan diukur dengan cara menimbang berat badan akhir di kurangi dengan berat awal bulan pemeliharaan dibagi lamanya hari dalam bulan tersebut, satuan dalam gram/ekor/hari.

\section{Konversi ransum (FCR)}

Konversi ransum dengan membandingkan jumlah ransum yang dikonsumsi pada dua bulan dengan pertambahan bobot badan pada bulan tersebut.

\section{Analisis Data}

Data penelitian dianalisis menggunakan Rancangan Acak Lengkap (RAL) dan bila ada hasil yang menunjukkan berbeda nyata dilanjutkan dengan menggunakan uji BNJ (Berbeda Nyata Jujur) untuk mengetahui seberapa besar perbedaannya.

\section{HASIL DAN PEMBAHASAN}

Hasil pengamatan pengurang penggunaan tepung ikan oleh hidolisat protein daging bekicot terfermentasi terhadap konsumsi ransum, bobot badan akhir, pertambahan bobot badan, dan konversi ransum pada ayam kampung super disajikan pada Tabel 2.

\section{Konsumsi ransum}

Hasil analisis keragaman menunjukkan bahwa penggunaan hidrolisat protein daging bekicot terfermentasi sebagai pengurangan penggunaan tepung ikan terhadap konsumsi tidak berpengaruh $(\mathrm{P}>0,05) \quad$ apabila dibandingkan dengan konsumsi ayam kontrol yang diberi ransum mengandung tepung ikan $100 \%$. Konsumsi ransum yang sama diduga bahwa penggunaan hidrolisat protein daging bekicot tidak mempengaruhi nafsu makan akibat perubahan rasa, bau, dan penampilan bentuk fisik pakan yang disusun karena diberikan dalam jumlah sedikit 5 sampai $20 \mathrm{ml}$ per kilogram pakan. Nafsu makan adalah keinginan untuk makan dan minum (Blundell, 2010). Hal ini biasanya digambarkan dalam hal rasa lapar dan kenyang (Corfe, Harden, Bull, \& Garaiova, 2015). Cairan hidrolisat yang ditambahkan sebagai bahan baru tidak memberikan dampak perubahan bau apalagi jika ditambahkan dalam konsentrasi yang sedikit. Menurut te Past et al., (2020) potensi nafsu makan ayam dapat diubah melalui mekanisme biologis dengan merangsang atau menghambat nafsu makan.

\section{Bobot badan akhir dan pertambahan bobot badan ayam kampung super}

Hasil analisis keragaman pada Tabel 2 dari penggunaan hidrolisat protein daging bekicot terfermentasi sebagai pengurangan penggunaan tepung ikan berpengaruh $(\mathrm{P}<0,05)$ terhadap bobot badan akhir pemeliharaan dan pertambahan bobot badan ayam kampung super, khususnya pada level perlakuan P4 yang menunjukkan nilai paling rendah. Hal ini memberikan gambaran bahwa penggunaan tepung ikan pada ransum ayam kampung super dapat diganti dengan hidrolisat protein daging bekicot fermentasi sampai 75\% dari penggunaan tepung ikan $8 \%$ pada ransum atau 6 kilogram tepung ikan dapat dikurangi dengan penggunaan hidrolisat protein daging bekicot sebanyak 15 $\mathrm{ml} / \mathrm{kg}$ ransum. Namun demikian, hidrolisat protein daging bekicot tidak dapat menggantikan $100 \%$ penggunaan tepung ikan dalam formula ransum.

Hasil penelitian menunjukkan rata-rata bobot badan akhir ayam kampung super pada 
Tabel 2. Rata-rata Performa Ayam Kampung Super

\begin{tabular}{ccccc}
\hline \multirow{2}{*}{ Perlakuan } & \multicolumn{4}{c}{ Parameter Penelitian } \\
\cline { 2 - 5 } & $\begin{array}{c}\text { Konsumsi } \\
\text { g/ekor/minggu }\end{array}$ & $\begin{array}{c}\text { Bobot } \\
\text { g/8 minggu }\end{array}$ & $\begin{array}{c}\text { PBB } \\
\text { g/ekor/minggu }\end{array}$ & FCR \\
\hline P0 & $199,38+1,45 \mathrm{~ns}$ & $705,70+29,09 \mathrm{a}$ & $83,43+3,55 \mathrm{a}$ & $2,36+0,06 \mathrm{a}$ \\
P1 & $198,89+1,5 \mathrm{~ns}$ & $669,21+04,43 \mathrm{a}$ & $78,93+0,59 \mathrm{a}$ & $2,44+0,02 \mathrm{a}$ \\
P2 & $198,60+1,78 \mathrm{~ns}$ & $673,00+19,46 \mathrm{a}$ & $79,45+2,38 \mathrm{a}$ & $2,45+0,03 \mathrm{a}$ \\
P3 & $198,57+0,30 \mathrm{~ns}$ & $696,62+31,62 \mathrm{a}$ & $82,38+3,38 \mathrm{a}$ & $2,43+0,03 \mathrm{a}$ \\
P4 & $198,35+0,94 \mathrm{~ns}$ & $652,33+27,49 \mathrm{~b}$ & $76,96+3,44 \mathrm{~b}$ & $2,53+0,09 \mathrm{~b}$ \\
\hline
\end{tabular}

Keterangan: P0 = Tepung ikan 8\% tanpa daging bekicot terfermentasi (Kontrol)

P1 = Tepung ikan $6 \%+$ hidrolisat protein daging keong fermentasi $5 \mathrm{ml} / \mathrm{kg}$ ransum

P2 = Tepung ikan 4\% + hidrolisat protein daging keong fermentasi $10 \mathrm{ml} / \mathrm{kg}$ ransum

P3 = Tepung ikan 2\% + hidrolisat protein daging keong fermentasi $15 \mathrm{ml} / \mathrm{kg} \mathrm{ransum}$

$\mathrm{P} 4=$ Tepung ikan $0 \%+$ hidrolisat protein daging keong fermentasi $20 \mathrm{ml} / \mathrm{kg}$ ransum

umur 8 minggu berada pada kisaran 652,33 $-705,70$ gram/ekor, bobot ini masih belum mencapai target yang diinginkan yaitu $0,8 \mathrm{~kg} /$ ekor, seperti yang dinyatakan oleh Muryanto (2005) yaitu dengan pemeliharaan intensif rata-rata bobot badan ayam kampung super umur 60 hari mencapai 0,85 kg. Hasil penelitian lain menyatakan bahwa ayam kampung super dapat mencapai berat $0,6-0,8 \mathrm{~kg}$ pada umur pemeliharaan 45 hari (Sofjan, 2012) dan pada umur 55-60 hari dapat mencapai 0,8-1 kg (Kaleka, 2015).

Pemakaian hidrolisat protein daging bekicot terfermentasi dapat mengurangi penggunaan tepung ikan sampai $75 \%$ diduga dapat menggantikan sejumlah protein yang hilang akibat pengurangan tepung ikan dengan menyediakan asam amino yang terdapat di dalam hidrolisat tersebut. Penyediaan asam amino hidrolisat daging bekicot ini memberikan dampak pada efisiensi penggunaan protein untuk memacu pertumbuhan karena asam amino merupakan bentuk sederhana protein yang mudah diserap oleh jaringan tubuh, dengan demikian asupan asam amino akan meningkatkan pertambahan bobot badan (Kingori et al., 2003).

Tingginya kecernaan protein berdampak pada rendahnya rasio efisiensi protein. Rasio efisiensi protein merupakan kemampuan tubuh seekor ternak mengubah protein menjadi bobot badan dan semakin tinggi nilainya menunjukkan semakin efisien (Situmorang et al., 2013). Selain itu, pemakaian hidrolisat protein daging bekicot terfermentasi pada ransum juga menunjukkan terjadinya keberagaman penggunaan bahan pakan sebagai sumber protein (Situmorang et al., 2013) serta peningkatan konsumsi dan asupan protein ke dalam tubuh tergantung pada keragaman sumber bahan pakan (Varianti et al., 2017).

\section{Pengaruh Suplemen Asam Amino Daging Bekicot Terfermentasi Terhadap Feed Conversion Ratio}

Hasil penelitian menunjukkan ratarata nilai FCR pada kisaran 2,36 - 2,53. FCR ayam kampung super menunjukkan pengaruh yang nyata $(\mathrm{P}<0,05)$. Pengurang penggunaan tepung ikan oleh hidrolisat protein daging bekicot sebanyak $20 \mathrm{ml} / \mathrm{kg}$ (P4) pada ransum memberiakan FCR nyata lebih tinggi dibandingan perlakuan lain (Tabel 2). Hal ini memberikan gambaran bahwa penggunaan hidrolisat protein daging bekicot terfermentasi sebagai pengurang penggunaan tepung ikan dapat dilakukan sampai $75 \%$ namun tidak dapat menggantikan $100 \%$ penggunaan tepung ikan dalam formula ransum karena kandungan protein hidrolisat protein daging bekicot tersebut hanya 1,39\%. Hal ini diduga karena kandungan energi ransum P4 yang rendah $(2217,55 \mathrm{kkal} / \mathrm{kg})$ sedangkan menurut Kaleka (2015), ayam kampung berumur 0-8 minggu membutuhkan energi $2.900 \mathrm{kkal} /$ kg dengan protein sekitar 18\%; Ca 0,9\%; dan $\mathrm{P} \quad 0,7 \%$. Energi ransum yang rendah akan menghambat pertumbuhan walaupun dapat dipenuhi dengan meningkatkan konsumsi. 


\section{KESIMPULAN}

Hidrolisat protein daging bekicot terfermentasi $15 \mathrm{ml} / \mathrm{kg}$ ransum dapat menggantikan tepung ikan sampai $75 \%$ dalam ransum terhadap konsumsi ransum, bobot badan akhir, pertambahan bobot badan, dan feed conversion ratio.

\section{DAFTAR PUSTAKA}

Beski, S., Swick, R., \& Iji, P. (2015). Specialised protein products in broiler chicken nutrition: A review. Anim. Nutr., 1, 47-53.

Biyatmoko, D. (2014). Performans produksi telur dan pendapatan usaha itik alabio petelur dalam pemanfaatan bekicot pohon fermentasi. Ziraa'ah, 39(2), 1412-1468.

Blundell, J., De Graaf, C., Hulshof, T., Jebb, S., Livingstone, B., Lluch, A., ... Westerterp, M. (2010). Appetite control: Methodological aspects of the evaluation of foods. Obesity Research, 11, 251- 270. https://doi. org/10.1111/j.1467-789X.2010.00714.X

Corfe, B. M., Harden, C. J., Bull, M., \& Garaiova, I. 2015. The multifactorial interplay of diet, the microbiome and appetite control: Current knowledge and future challenges. Proceedings of the Nutrition Society, 74, 235- 244. https://doi.org/10.1017/ S0029665114001670

Irianto, H. E. (2013). Produk Fermentasi Ikan. Penebar Swadaya.

Kaleka. (2015). Beternak Ayam Kampung Super Tanpa Bau. Arcitra.

Kingori, A. M., Tuitoek, J. K., Muiruri, H. K., \& Wachira, A. M. (2003). Protein requirements of growing indigenous chickens during the 14-21 weeks growing period. South African Journal of Animal Sciences, 33(2), 78-82.

Ma'rifah, B., Atmomarsono, U., \& Suthama, N. (2013). Nitrogen Retention and Productive Performance of Crossbred Native Chicken Due to Feeding Effect of Kayambang (Salvinia molesta). International Journal of Science and Engineering, 5(1), 19-23.
Muryanto. (2005). Pengembangan Ayam Hibrida (Ayam Potong Lokal). Petunjuk Teknis. Balai Pengkajian Teknologi Pertanian Jawa Tengah.

Nawawi, T., \& Nurrohmah. (2013). Pakan Ayam Kampung. Penebar Swadaya.

Phakde, G. K., Elavarasan, \& Shamasundar, B. A. (2014). Angiotensin I converting enzyme (ace) inhibitory activity and antioxidant activity of fermented fish product ngarias influenced by fermentation period. International Journal of Pharma and Bio Sciences, 5(2), 134-142.

Situmorang, N. A., Mahfudz, L. D., \& Atmomarsono, U. (2013). Pengaruh pemberian tepung rumput laut (Gracilaria verrucosa) dalam ransum terhadap efisiensi penggunaan protein ayam broiler. J. Anim. Agric., 2(2), 49-56.

Sofjan, I. (2012). Ayam Kampung Unggul Balintnak. Badan Penelitian dan Pengembangan Pertanian.

Sriyanto. (2013). Pengembangan ayam hibrida dalam rangka mendukung swasembada daging di Jawa Tengah (studi di Kabupaten Klaten dan Temanggung). Jurnal Litbang Provinsi Jawa Tengah, 11(2), 188-200.

Suprijatna, E., Atmomarsono, U., \& Kartasudjana, R. (2008). Ilmu Dasar Ternak Unggas. Penebar Swadaya.

te Pas, M.F.W., Randy Borg,Nico J. H. Buddiger,Benjamin J. Wood,Johanna M. J. Rebel,Marinus M. van Krimpen,Mario P. L. Calus,Jong-Eun Park,Dirkjan Schokker,. 2020. Regulating appetite in broilers for improving body and muscle development - A review. J Anim Physiol Anim Nutr ;104:1819-1834.

Varianti, N. I., Atmomarsono, U., \& Mahfudz, L. D. (2017). Pengaruh Pemberian Pakan dengan Sumber Protein Berbeda terhadap Efisiensi Penggunaan Protein Ayam Lokal Persilangan. Jurnal Agripet, 17(1), 53-59.

Wakhid, A. (2010). Buku Pintar Beternak \& Berbisnis Itik. Agro Media Pustaka. 